$\operatorname{CoCOS~(2003),~} 1501-11$

Printed in Sri Lanka

\title{
EFFECT OF MULCHES AND COVER CROPS ON WATER STATUS AND GAS EXCHANGE OF COCONUT (Cocos nucifera L.) PALMS IN GRAVELLY SOILS
}

\author{
C. S. Ranasinghe, R. D. N. Premasiri and L. R. S. Silva \\ Coconut Research Institute, Lunuwila, Sri Lanka.
}

\begin{abstract}
Two field experiments were conducted in gravelly soils (Andigama series) in Sri Lanka to investigate the effect of different mulches and cover crops, utilized to conserve soil moisture, on water status, gas exchange and related soil parameters of coconut palms (Cocos nucifera L. var typica). The results revealed that mulching only the manure circle was not effective in improving the palm water status, gas exchange and soil water status during dry periods in Andigama soil series (gravelly soils). The mulches tested were coconut husks, coir dust, straw, black polythene and dried coconut fronds. The palms were equally sensitive to soil water depletion and responded to the water deficit by increasing the stomatal resistance irrespective of the mulch treatment. When the manure circle was mulched with dried coconut fronds, and the rest of the land was also mulched with a five $\mathrm{cm}$ thick layer of coir dust, the palms showed an improved gas exchange ability than palms growing in bare land or with cover crops during the dry period.
\end{abstract}

Key words: Cocos nucifera, mulching, cover crops, leaf water relations, soil temperature, soil water relations, coir dust, black polythene

\section{INTRODUCTION}

The coconut palm, a tree crop which exhibits continuous concurrent vegetative and reproductive phases of growth, requires a regular supply of water to realize and maintain its potential growth and nut production. As coconut is mostly cultivated under rain-fed conditions in Sri Lanka, soil moisture stress during the rain-free seasons is an acute problem, particularly in gravelly soils (eg. Andigama series), irrespective of the agroecological region (Somasiri et al., 1994; Vidhana Arachchi, 1998). In the intermediate rainfall zone of Sri Lanka where coconut cultivation is most concentrated, the bimodal distribution of rainfall results in two distinct periods of water stress, sometimes extending for more than three months each year. During extended periods of soil moisture stress, the cells of the absorption zone of coconut roots become inactive by suberization and dehydration, adversely affecting the water and nutrient absorption processes (Vidhana Arachchi et al., 1996; Vidhana Arachchi et al., 2000). 
Soil moisture stress is known to retard the growth of young palms, delay initiation of flowering, increase button nut shedding and immature nut fall and reduce the number and size of nuts (Abeywardena, 1971).

Transpiration through leaves is necessary for healthy growth of a palm as it lowers leaf temperature during hot weather. Transpiration aids the transport of water and nutrients to the canopy of the palm for the synthesis of organic food materials. In the dry season, if the absorption of the water is insufficient to balance the loss, the palm will close stomata to prevent dehydration. This will limit the $\mathrm{CO}_{2}$ intake by the leaf, the movement of nutrients to the canopy and ultimately affect the nut yield (Taiz and Zeiger, 1991). To reduce these constraints and minimize the drought damage, a number of moisture conservation practices have been recommended by the Coconut Research Institute (Liyanage, 1999). The ability of different mulching material to conserve soil moisture in coconut has been investigated in sandy loam soils and, dead mulching was found to be the most efficient practice (Varadan et al., 1990; Vidhana Arachchi, 1998). However, a detailed physiological study on the efficacy of these practices in improving water status of coconut palms has not been reported. Such information is vital in planning and implementing soil moisture conservation methods appropriate for different land suitability classes (Somasiri et al., 1994). The aim of the present study was, therefore, to determine the effect of different soil moisture conservation practices utilizing mulches and cover crops, on water status and gas exchange of coconut palms in gravelly soils in the intermediate rainfall zone of Sri Lanka.

\section{MATERIALS AND METHODS}

\section{Experimental site and planting material}

The field experiments 1 and 2 described below were conducted at Ratmalagara Estate, Madampe, located in the intermediate rainfall zone of the low country of Sri Lanka $\left(08^{\circ} 02 \mathrm{~N}, 79^{\circ} \mathrm{E} ; 35 \mathrm{~m}\right.$ altitude). Soils at this site were gravelly and classified as the Andigama series belonging to the great soil group, Red Yellow Podzolic soils and moderately suitable land class for coconut (Somasiri et al., 1994; Vidhana Arachchi et al., 1996). The coconut palms (Cocos nucifera $L$ var. typica) selected for the study were 16 years old and were subjected to the following soil moisture conservation treatments, for a period of three years and data collection on water status and gas exchange was done during the second and third years. The design of the experiments was a completely randomized single-tree plot with six replicates per treatment. 


\section{Treatments}

\section{Experiment 1}

This experiment was conducted to study the effect of different soil moisture conservation treatments applied only to the manure circle. The manure circle ( $1.75 \mathrm{~m}$ radius from the bole) of coconut palms was mulched with the following material. The land surrounding the manure circle was treated uniformly (controlled grass cover).

$T_{1}$ - Control (without mulch)

$\mathrm{T}_{2}-\quad$ Husk mulch (250 husks)

$\mathrm{T}_{3}$ - Coir dust mulch $(10 \mathrm{~cm}$ thick)

$\mathrm{T}_{4}$ - $\quad$ Straw mulch (5 $\mathrm{cm}$ thick)

$\mathrm{T}_{5}$ - $\quad$ Black polythene mulch (400 gauge black polythene cover with eight holes)

$T_{6}$ - Dried coconut frond mulch (12-14 fronds per annum)

\section{Experiment 2}

The experiment was conducted to study the effect of different moisture conservation treatments applied to the entire land surrounding the manure circles. The manure circle of coconut palms ( $1.75 \mathrm{~m}$ radius from the bole) was mulched with 12-14 dried coconut fronds in all treatments. The surrounding ground area (total area excluding the manure circle) was subjected to following treatments.

$T_{1}$ - Control - clean weeded at monthly intervals

$T_{2}-$. Brachiaria brizantha - grass cover crop slashed every 6 months

$\mathrm{T}_{3}$ - $\quad$ Brachiaria brizantha - grass cover crop allowed to grow freely

$\mathrm{T}_{4}$ - Pueraria cover crop

$\mathrm{T}_{5}$ - Coir dust mulch $(5 \mathrm{~cm}$ thick)

\section{Collection of data}

\section{Experiment 1}

Gas exchange (rate of transpiration, stomatal, diffusive resistance) and water status (leaf water potential and relative water content) parameters were measured during wet (immediately after a good rainy season) and dry (after a 60 day period without rain) periods on the central leaflets from both sides of ninth frond (counting the youngest fully open leaf as one), between 9.00 a.m. and 1.00 p.m. with full sun. Soil water potential at $50 \mathrm{~cm}$ depth and soil temperature at $30 \mathrm{~cm}$ depth were measured in the manure circle (details are given below). 


\section{Gas exchange parameters}

The rate of transpiration and stomatal diffusive resistance were measured using the LI-1600 Steady Porometer (LI-COR Inc, Lincoln, USA).

\section{Water status parameters}

Leaf water potential was measured using a Scholander type pressure chamber (Soil Moisture Equip. Corp, Santa Barbara, California, USA). Leaflets were detached from the adult palm, and they were sealed in the chamber as soon as possible to prevent evaporation of water from the leaf. Compressed air was used to determine the pressure necessary to produce incipient sap exudation, which corresponds to the balancing xylem sap negative pressure (Scholander et al., 1965).

The Relative Water Content of the leaves was calculated using the following formula (Weatherley, 1950)

$$
\begin{aligned}
& \text { RWC }=(F W-D W) /(T W-D W) \times 100 \\
& \text { FW = Fresh weight of the sample } \\
& \text { DW = Dry weight of the sample } \\
& \text { TW = Fully turgid weight of the sample }
\end{aligned}
$$

\section{Soil water potential $\left(\Psi_{\text {soil }}\right)$}

Water potential of the soil was measured by filter paper method (Hamblin, 1981). Soils at $50 \mathrm{~cm}$ depth in the manure circle were sampled and Whatman No. 42 filter papers were maintained in close contact with the soil for 4 days in airtight aluminium containers to allow the filter paper to equilibrate with the soil moisture. The wet and oven dried $\left(105^{\circ} \mathrm{C}\right.$ to a constant weight) weights of the filter paper were recorded to estimate soil water potential ( $\left.\Psi_{\text {soil }}\right)$ using the following equation.

$$
\ln \left(\Psi_{\text {soil }}\right)=-2.397-3.683 \ln F
$$

$F=$ fractional gravimetric water content of the filter paper

\section{Soil temperature}

Diurnal variation in soil temperature in the manure circle (under the mulch) of control (T1), coir dust (T3) and black polythene (T5) mulched palms at 30 $\mathrm{cm}$ depth was measured from 8.00 to 18.00 hours at two hourly intervals during dry period, using soil thermometers. 


\section{Experiment 2}

Rate of transpiration, stomatal diffusive resistance and water potential of leaves of the palms were measured. during wet and dry periods, on the central leaflets from both sides of ninth frond, between 9.00 a.m. and 1.00 p.m. with full sun (methods were described above).

\section{RESULTS}

\section{Experiment 1}

During the wet period there was no difference, between the treatments, in the transpiration rate of coconut palms. With the onset of drought, transpiration rate declined and there was no significant difference in transpiration between control $\left(T_{1}\right)$ and mulched palms $\left(T_{2}, T_{3}, T_{4}, T_{5}\right.$ and $\left.T_{6}\right)$. However, the highest rate of transpiration during the dry period was observed in coir dust mulched palms $\left(T_{3}\right)$ and it was significantly higher than in palms mulched with other materials $\left(T_{2}, T_{4}, T_{5}\right.$ and $\left.T_{6}\right)$. During the dry period, the lowest rate of transpiration was observed in palms mulched with black polythene (Table 1).

During both wet and dry periods there was no statistically significant difference in the stomatal diffusive resistance between control and mulched palms. However, the highest stomatal resistance was observed during the dry period, in palms mulched with black polythene. Furthermore, with the onset of drought there was a 12-25 fold increase in the stomatal resistance of all the palms compared to wet period (Table 1).

Table 1: Effect of mulching the manure circle with different materials on rate of transpiration and stomatal diffusive resistance of coconut palms during wet and dry periods of the year

\begin{tabular}{lcccc}
\hline \multicolumn{1}{c}{ Treatment } & $\begin{array}{c}\text { Rate of transpiration } \\
\left(\mu \mathrm{cm}^{-2} \mathbf{~ s}^{-1}\right)\end{array}$ & \multicolumn{2}{c}{$\begin{array}{c}\text { Stomatal diffusive } \\
\text { resistance } \\
\left(\mathrm{cm} \mathrm{s}^{-1}\right)\end{array}$} \\
\hline & Wet period & Dry period & Wet period & Dry period \\
\hline Control & $4.96^{\mathrm{a}}$ & $0.89^{\mathrm{ab}}$ & $3.03^{\mathrm{a}}$ & $35.80^{\mathrm{a}}$ \\
Husk mulch & $4.71^{\mathrm{a}}$ & $0.64^{\mathrm{b}}$ & $3: 18^{\mathrm{a}}$ & $49.77^{\mathrm{a}}$ \\
Coir dust mulch & $5.45^{\mathrm{a}}$ & $1.55^{\mathrm{a}}$ & $2.93^{\mathrm{a}}$ & $50.68^{\mathrm{a}}$ \\
Straw mulch & $4.99^{\mathrm{a}}$ & $0.48^{\mathrm{b}}$ & $2.62^{\mathrm{a}}$ & $59.62^{\mathrm{a}}$ \\
Black polythene mulch & $4.77^{\mathrm{a}}$ & $0.38^{\mathrm{b}}$ & $3.02^{\mathrm{a}}$ & $78.43^{\mathrm{a}}$ \\
Dried coconut frond mulch & $4.67^{\mathrm{a}}$ & $0.48^{\mathrm{b}}$ & $3.39^{\mathrm{a}}$ & $69.17^{\mathrm{a}}$ \\
\hline
\end{tabular}

Values are means and means with the same letters are not statistically significant within a column at $p \leq 0.05$ ) 
Leaf water potential of the palms was unaffected by mulching during wet period and was approximately $-1 \mathrm{MPa}$ in both control and mulched palms. During dry period the leaf water potential of all the palms was increased compared to wet period and husk mulched palms showed a significantly lower water potential than in other palms (Table 2).

Relative water content of the leaves was also unaffected by mulching during both wet and dry periods. However, relative water content was less during the dry period than in the wet period in all treatments (Table 2).

Table 2: Effect of mulching the manure circle with different materials on leaf water potential and relative water content of leaves of coconut palms during wet and dry periods of the year.

\begin{tabular}{lcccc}
\hline Treatment & \multicolumn{2}{c}{$\begin{array}{c}\text { Leaf water potential } \\
(\mathrm{MPa})\end{array}$} & $\begin{array}{c}\text { Relative water content } \\
\text { (leaf) (\%) }\end{array}$ \\
\hline & Wet period & Dry period & Wet period & Dry period \\
\hline Control & $-1.19^{\mathrm{a}}$ & $-0.58^{\mathrm{b}}$ & $93.96^{\mathrm{a}}$ & $91.47^{\mathrm{a}}$ \\
Husk mulch & $-1.06^{\mathrm{a}}$ & $-0.73^{\mathrm{a}}$ & $94.59^{\mathrm{a}}$ & $92.13^{\mathrm{a}}$ \\
Coir dust mulch & $-1.23^{\mathrm{a}}$ & $-0.53^{\mathrm{b}}$ & $94.28^{\mathrm{a}}$ & $91.56^{\mathrm{a}}$ \\
Straw mulch & $-1.24^{\mathrm{a}}$ & $-0.59^{\mathrm{b}}$ & $95.31^{\mathrm{a}}$ & $90.21^{\mathrm{a}}$ \\
Black polythene mulch & $-0.97^{\mathrm{a}}$ & $-0.52^{\mathrm{b}}$ & $95.41^{\mathrm{a}}$ & $92.78^{\mathrm{a}}$ \\
Dried coconut frond mulch & $-1.23^{\mathrm{a}}$ & $-0.57^{\mathrm{b}}$ & $95.13^{\mathrm{a}}$ & $93.65^{\mathrm{a}}$ \\
\hline
\end{tabular}

Values are means and means with the same letters are not statistically significant within a column at $p \leq 0.05$ )

The soil water potential in the manure circle of control palms was similar to that of mulched palms during both wet and dry periods. However, the lowest soil water potential was under the polythene mulch irrespective of the season (wet or dry) and the highest soil water potential was under the coir dust mulch during the dry period although the effects were not significant. With the onset of drought the soil water potential in all treatments declined compared to wet period (Table 3).

Table 3: Effect of different mulches on the soil water potential (MPa) in the manure circle during wet and dry periods of the year.

\begin{tabular}{lcc}
\hline \multicolumn{1}{c}{ Treatment } & Wot period & Dry period \\
\hline Control & $-0.41^{\mathrm{a}}$ & $-2.05^{\mathrm{a}}$ \\
Husk mulch & $-0.40^{\mathrm{a}}$ & $-2.32^{\mathrm{a}}$ \\
Coir dust mulch & $-0.36^{\mathrm{a}}$ & $-1.58^{\mathrm{a}}$ \\
Straw mulch & $-0.33^{\mathrm{a}}$ & $-2.12^{\mathrm{a}}$ \\
Black polythene mulch & $-0.56^{\mathrm{a}}$ & $-2.90^{\mathrm{a}}$ \\
Dried coconut frond mulch & $-0.30^{\mathrm{a}}$ & $-2.21^{\mathrm{a}}$ \\
\hline
\end{tabular}

Values are means and means with the same letters are not statistically significant within a column at $p \leq 0.05$ ) 
The soil temperature under black polythene mulch was significantly.higher, and under coir dust mulch was significantly lower than in the control throughout the day, during the dry period. The mean temperature increase by black polythene mulch was $1.1^{\circ} \mathrm{C}$ and decrease by coir dust mulch was $1.3^{\circ} \mathrm{C}$ compared to the control (no mulch) (Table 4).

Table 4: $\quad$ Effect of different mulches on diurnal soil temperature in the manure circle, $30 \mathrm{~cm}$ below the mulch.

\begin{tabular}{lllllll}
\hline \multicolumn{1}{c}{ Treatment } & \multicolumn{7}{c}{ Time $(\mathrm{h})$} \\
\hline & $\mathbf{8 : 0 0}$ & $10: 00$ & $12: 00$ & $14: 00$ & $16: 00$ & $18: 00$ \\
\hline Control & $29.0^{\circ}$ & $29.3^{\mathrm{b}}$ & $29.4^{\mathrm{o}}$ & $29.7^{\mathrm{o}}$ & $30.3^{\mathrm{o}}$ & $30.6^{\mathrm{o}}$ \\
Black polythene & $30.0^{\mathrm{a}}$ & $30.4^{\mathrm{a}}$ & $30.4^{\mathrm{a}}$ & $30.8^{\mathrm{a}}$ & $31.3^{\mathrm{a}}$ & $31.6^{\mathrm{a}}$ \\
Coir dust & $28.4^{\mathrm{c}}$ & $28.4^{\mathrm{c}}$ & $28.5^{\mathrm{c}}$ & $28.6^{\mathrm{c}}$ & $27.7^{\mathrm{c}}$ & $29.0^{\mathrm{c}}$ \\
\hline
\end{tabular}

Values are means and means with the same letters are not statistically significant within a column at $\mathrm{p} \leq 0.05$ )

\section{Experiment 2:}

During wet periods, the treatments did not affect rate of transpiration, stomatal diffusive resistance and leaf water potential of coconut palms. With the onset of drought transpiration rate decreased and stomatal resistance increased in all the palms irrespective of the treatment. However, in the palms mulched with coir dust, the transpiration rate was significantly higher and stomatal diffusive resistance was significantly lower than those in other treatments, during dry periods. The leaf water potential of palms in all treatments was about $-1 \mathrm{MPa}$ during both wet and dry periods. The leaf water potential of palms in the Brachiaria grass cover slashed every six months (T2) showed significantly lower water potential than control palms, during dry period (Table 5). 
Table 5: Effect of different moisture conservation treatments applied to the entire land surrounding the manure circles on rate of transpiration, stomatal diffusive resistance and leaf water potential of coconut palms during wet and dry periods of the year

\begin{tabular}{lcccccc}
\hline & \multicolumn{2}{c}{$\begin{array}{l}\text { Rate of Transpiration } \\
\left(\mu \mathrm{g} \mathrm{cm}^{-2} \mathrm{~s}^{-1}\right)\end{array}$} & \multicolumn{2}{c}{$\begin{array}{c}\text { Stomatal diffusive } \\
\text { resistance }\left(\mathrm{s} \mathrm{cm}^{-1}\right)\end{array}$} & \multicolumn{2}{c}{$\begin{array}{c}\text { Leaf water } \\
\text { potential }\end{array}$} \\
\hline & Wet & Dry & Wet & Dry & Wet & Dry \\
\hline Bare land (control) & $2.306^{\mathrm{bc}}$ & $0.896^{\mathrm{b}}$ & $12.996^{\mathrm{ab}}$ & $34.08^{\mathrm{ab}}$ & $-1.08^{\mathrm{a}}$ & $-0.90^{\mathrm{bc}}$ \\
Controlled grass & $3.834^{\mathrm{ab}}$ & $0.740^{\mathrm{b}}$ & $6.562^{\mathrm{bc}}$ & $48.27^{\mathrm{a}}$ & $-1.24^{\mathrm{a}}$ & $-1.08^{\mathrm{a}}$ \\
Uncontrolled grass & $2.656^{\mathrm{bc}}$ & $0.896^{\mathrm{b}}$ & $8.434^{\mathrm{bc}}$ & $36.67^{\mathrm{ab}}$ & $-1.21^{\mathrm{a}}$ & $-1.00^{\mathrm{abc}}$ \\
Pueraria & $1.946^{\mathrm{c}}$ & $0.894^{\mathrm{b}}$ & $16.396^{\mathrm{a}}$ & $36.83^{\mathrm{ab}}$ & $-1.07^{\mathrm{a}}$ & $-0.99^{\mathrm{abc}}$ \\
Coir dust & $3.074^{\mathrm{bc}}$ & $1.684^{\mathrm{a}}$ & $8.368^{\mathrm{bc}}$ & $20.01^{\mathrm{c}}$ & $-1.20^{\mathrm{a}}$ & $-1.06^{\mathrm{ab}}$ \\
\hline
\end{tabular}

Values are means and means with the same letters are not statistically significant within a column at $p \leq 0.05$ )

\section{DISCUSSION}

The application of mulch, (coconut husks, coir dust, straw, black polythene or dried coconut fronds) only to the manure circle, was not effective in improving water status and gas exchange of palms or water status of soil during dry periods in Andigama soil series (gravelly soils). All the palms, irrespective of the mulch treatment, were equally sensitive to soil water depletion and responded to water deficit by increasing the stomatal resistance. These results also confirm that the stomatal regulation is the key factor controlling the water balance of coconut as also observed by Rajagopal et al., (1990); Jayasekara et al., (1993); Shivashankar et al., (1993) and Repellin et al., (1997). One surprising observation was that the leaf water potential (xylem sap tension) of mulched and unmulched palms was higher in the dry period than in the wet period, apparently due to stomatal responses to dry period as also observed by Milburn and Zimmermann, (1977) in coconut. The pattern of increase in stomatal resistance was not related to variation in leaf water potential. This indicates that early stomatal responses to soil water depletion are not triggered by changes in leaf water potential. This phenomenon has been extensively studied and documented for other species as well. Such studies have clearly demonstrated that, besides controlling factors at the leaf level, there is a root-to-leaf communication, independent of the leaf water status, via the hormone Abscisic acid, that informs the shoot about changes in the root environment, eg. increasing soil dryness (Blackman and Davies, 1985). 
Repellin et al., (1997) suggested that this mechanism exists in coconut, and hence $A B A$ might be the stomatal mediator.

Among the manure circle mulching treatments, palms mulched with black polythene seemed to suffer most from a water deficit condition during dry periods. These palms showed the lowest transpiration, highest stomatal diffusive resistance and lowest soil water potential. Black polythene mulch increased the soil temperature whilst the coir dust mulch decreased it compared to palms with no mulch. Varadan et al., (1990) also reported that despite the fact that the polythene mulch could increase the soil moisture content, it could also increase the soil temperature under the mulch, irrespective of the frequency of irrigation. This might be attributed to the effect of polythene in cutting off air circulation beneath it and to the increased heat absorption by it. Mulching with coir dust may avoid direct heating of soil, thus preventing the rise in soil temperature.

Palms where the manure circle was mulched with dried coconut fronds and the surrounding land also mulched with a five $\mathrm{cm}$ thick layer of coir dust, showed an improved gas exchange capacity during dry periods than those growing in bare land or with cover crops (controlled and uncontrolled Brachiaria grass and Pueraria) (experiment 2). This could be attributed to the availability of more moisture under the coir dust mulch than under cover crops or bare land. The coir dust mulch also increased the growth of the palms and number of nuts per palm by about $40 \%$ over the other treatments, bare land and cover crops (K. B. Dassanayake, unpublished).

\section{CONCLUSION}

Limiting the application of soil moisture conservation practices to mulching the manure circle only does not improve water status, gas exchange capacity or soil water potential of coconut grown in drought prone soils. A positive and desirable response, in terms of gas exchange parameters, was recorded only when the entire land was mulched with coir dust.

\section{ACKNOWLEDGEMENT}

The experimental plots were maintained by Soils and Plant Nutrition Division and Agronomy Division of CRISL. I am most grateful to Dr L P Vidhana Arachchi and Dr K B Dassanayake (former Research Officers of CRI) for their invaluable assistance. The skillful assistance of the staff, Plant Physiology Division in data collection is gratefully acknowledged. Sincere thanks are due to Head and staff of Biometry Division for the assistance in analysis of data. 


\section{REFERENCES}

Abeywardena, V. (1971). Crop losses in coconut through button shedding and immature nut fall Ceylon Coconut Planters' Review 6, 97-105.

Blackman, P.G. and Davies, W.J. (1985). Root to shoot communication in maize plants and the effect of soil drying. Journal of Experimental Botany 36, 39-48.

Hamblin, A.P. (1981). Filter paper method for routine measurement of field water potential. Journal of Hydrology 53, 355-360.

Jayasekara, C., Ranasinghe, C.S and Mathes, D.T. (1993). Screening for high yield and drought tolerance in coconut. In: MK Nair, HH Khan, $P$ Gopalasundaram, EW Bhaskara Rao (eds) Advances in Coconut Research and Development. Oxford and IBH publishing Co. Pvt. Ltd., New Delhi. pp 209218.

Liyanage, M.De.S. (1999). A guide to scientific cultivation and management of coconut. Pp 51-58.

Milburn, J.A and Zimmermann, M.H. (1977).Preliminary studies on sapflow in Cocos nucifera L. 1. Water relations and xylem transport. New Phytologist 79, 535541.

Rajagopal, V. Kasturibai, K.V and Voleti, S.R. (1990). Screening of coconut genotypes for drought tolerance. Oleagineux 45, 215-223.

Repellin, A., Daniel, C. and Zuily-Fodil, Y. (1997). Merits of physiological tests for characterizing the performance of different coconut varieties subjected to drought. Oleagineux 49 (4), 155-169.

Shivashankar, S. George, K.M. Rajagopal, V. and Voleti, S.R. (1993). Comparative physiological studies on the drought tolerance of three hybrids of coconut. Oleagineux 48, 357-360.

Scholander, P.F. Hammel, H.T. Bradstreet, E.D. Hemmingsen, E. Sap pressure in vascular plants. Science 148, 339.et al., 1965

Somasiri, L.L.W. Nadarajah, N. Amarasiri, L. and Gunathilake, H.A.J. (1994). In: Land suitability assessment of coconut growing areas in the coconut triangle. C R Panabokke and Mahindapala R (Eds) The Coconut Research Institute, Sri Lanka.

Taiz, L and Zeiger, E. (1991). Plant Physiology. The Benjamin / Cumming Company, Inc, USA.

Varadan, K.M. Madhavachandran, K. Joseph, E.J and Jayakumar, M. (1990), Effect of irrigation and mulching on soil moisture and soil temperature under coconut. Journal of Plantation Crops 18 (1); 5-58. 
Vidhana Arachchi, L.P. Mapa, R.B. Yapa, P.A..J. and Somapala, H. (1996). Characterization of soil physical properties in Andigama series in relation to coconut root growth. Tropical Agricultural Research 8, 64-77.

Vidhana Arachchi, L.P. (1998), An evaluation of different mulches used in the soil moisture conservation of coconut lands. CORD XIV (2): 12-27.

Vidhana Arachchi, L.P. Yapa, P.A.. J. Mapa, R.B. and Somapala, H. (2000). Soil physical constraints and their effect on morphological characters of coconut (Cocos nucifera L.) roots. CORD XVI (1): 14-33.

Weatherley, P.E. (1950), Studies on the water relations of the cotton plant. 1. The field measurements of the water deficits in the leaves. New Phytologist 49, 81 97. 